\title{
Factor Analysis of Stream Sediment Geochemical Data from Onyami Drainage System, Southwestern Nigeria
}

\author{
Ovie Odokuma-Alonge ${ }^{1}$, John Adeyinka Adekoya ${ }^{2}$ \\ ${ }^{1}$ Department of Geology, University of Benin, Benin City, Nigeria \\ ${ }^{2}$ Department of Applied Geology, The Federal University of Technology, Akure, Nigeria \\ Email: odoksalo@yahoo.com, yinkadekoya2002@yahoo.com
}

Received October 26, 2012; revised January 27, 2013; accepted February 24, 2013

Copyright (C) 2013 Ovie Odokuma-Alonge, John Adeyinka Adekoya. This is an open access article distributed under the Creative Commons Attribution License, which permits unrestricted use, distribution, and reproduction in any medium, provided the original work is properly cited.

\begin{abstract}
An R-mode quartimax rotated factor matrix was applied to a statistical study of stream sediment geochemical data from Onyami drainage system within Igarra area in southwestern Nigeria. The area is underlain by the gneiss-migmatite complex, the low grade supracrustal schist belts and the Pan-African granitoids which intruded both the gneiss-migmatite complex and the supracrustal units. A four-factor model which accounts for $76.49 \%$ of the total variance of the stream sediment geochemical data was established. Factor 1 (Sc-Ga-V-La-Ni-Co-Ag-Bi-Sr-Pb-Hf-Nb-Cu-Cr) probably defines an underlying complex granitic lithology with contributions from mafic and ultramafic rocks. Factor 2 (Th-U) is attributable to a granitic lithology which reflects the parent rock as the influencing factor. Factor 3 (Mo-Nb-Zn) appears to define a minor sulphide mineralization associated with granitic rocks that intruded the schists and granite gneiss in the area. Factor 4 indicates the occurrence of gold and its pathfinder element, As, in the study area. This inference is consistent with the reported occurrence and mining of gold during the colonial era in Dagbala, which lies within the Onyami river catchment area.
\end{abstract}

Keywords: Stream Sediment Survey; Geochemistry; Factor Analysis

\section{Introduction}

Factor analysis of geochemical prospecting data has been applied for the interpretation of stream sediments and soil surveys [1-4]. R-mode factor analysis in particular gives useful information concerning relationships between elements and is more widely used for the interpretation of geochemical data. It identifies groups of elements which behave similarly in a particular geochemical environment and could serve as a pointer to elemental associations present in economic mineralization within a drainage catchment area. The geochemical project which gave rise to this paper involved a stream sediment survey of Onyami drainage system in Igarra district within a forested terrain of southwestern Nigeria. It was undertaken as part of a long-term plan initiated by the Postgraduate Research Group of the Department of Applied Geology, The Federal University of Technology, Akure (FUTA), Nigeria to search for metallic mineralization, especially gold, in the district. The drive for the research is predicated on the similarity of the geological setting of the district (dominated by the Igarra schist belt) to those of auriferous Birnin Gwari, Maru and Ife-Ilesha Schist Belts in other parts of Nigeria $[5,6]$. This paper aims at evaluating the inter-element relationship, employing R-mode factor analysis, in the geochemical data derived from a stream sediment survey of the Onyami drainage system. This is done with a view to identifying elements and target areas that are worth further prospecting pursuit.

\section{Geology of the Area}

The area under investigation is situated in the southwestern part of the Precambrian Basement Complex of Nigeria (Figure 1). It falls between latitude $7^{\circ} 12^{\prime} \mathrm{N}$ and $7^{\circ} 30^{\prime} \mathrm{N}$ and longitude $6^{\circ} 00^{\prime} \mathrm{E}$ and $6^{\circ} 15^{\prime}$. The total area covered is about $900 \mathrm{~km}^{2}$. The Precambrian basement complex of Nigeria has been classified into four major groups or divisions on a tectono-stratigraphic basis [7]. These major rock groups consist of the Gneiss-Migmatite-Quartzite complex, the Schist Belts, the Pan African Granites (Older Granites and associated granitoids), and Minor Felsic and Mafic Intrusives. The Onyami River and its tributaries covered in the stream sediment survey 


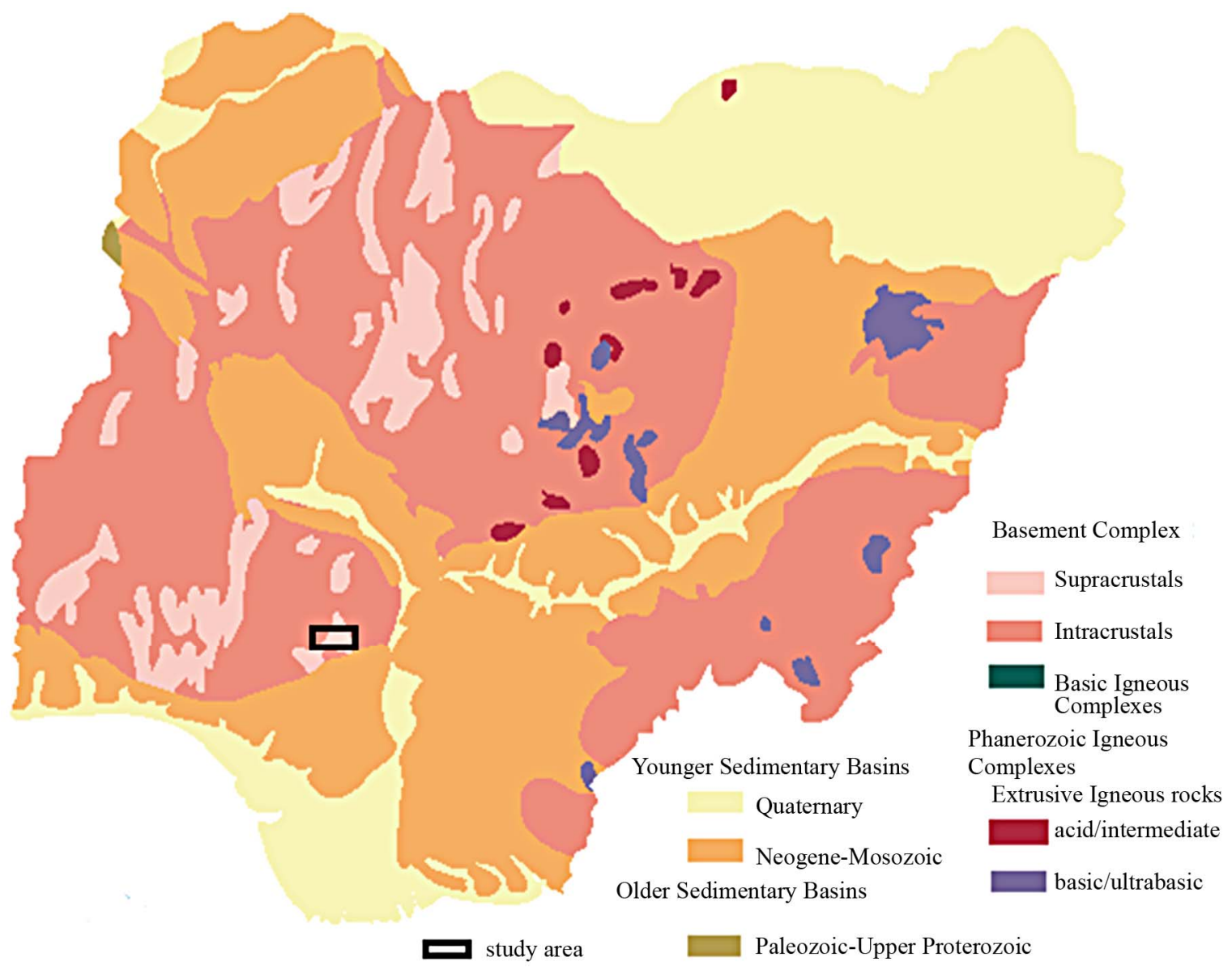

Figure 1. Geological map of Nigeria (modified after [8]) showing the study area.

drain the Igarra area which is underlain by syn to latetectonic porphyritic and non-porphyritic granites, the Igarra Schist Belt and gneiss-migmatite complex. Dykes and veins of lamprophyre, syenite, dolerite, quartz and pegmatite are intruded into the various rock groups. The Igarra Schist Belt underlies most part of the study area and it consists of essentially low grade metasediments composed of phyllites, quartzite and quartz schist, metaconglomerates, quartz-mica and mica schists, flaggy gneiss, marble, calc-gneiss and calc-silicate rocks [9]. Generally the metasediments are considered as a supracrustal cover over the gneiss-migmatite basement. The granites, typified by the Igarra granite batholith, intrude the metasediments with varying contact metamorphic effects. Fine disseminations of sulphide occur in places in the nonporphyritic granite.

\section{Sampling and Analytical Methods}

Fifty-nine stream-sediment samples were collected at an average interval of $2-3 \mathrm{~km}$ along the Onyami River and its tributaries in the Igarra district. The samples were taken with a plastic scoop in the centre of the active streams into pre-labeled baft bags and transported to the labora- tory for analysis. They were air-dried for two weeks, disaggregated using porcelain mortar and pestle that are cleaned with acetone after each disaggregation operation and sieved to minus 80 mesh (177 microns). The sieved fraction was further homogenized and prepared ready for analysis in the Activation Laboratories Ltd, Ancaster, Ontario, Canada.

One gram of the homogenized sample was digested with $6 \mathrm{ml}$ of a $2-2-2 \mathrm{ml}$ mixture of $\mathrm{HCl}-\mathrm{HNO}_{3}-\mathrm{H}_{2} \mathrm{O}$ at $95^{\circ} \mathrm{C}$ for one hour. After filtration, the leached solution was diluted with ultra pure water to $20 \mathrm{ml}$ inside a volumetric flask. The concentrations of 29 minor and trace elements were determined by Inductively Coupled PlasmaMass Spectrophotometer (ICP-MS). Analytical precision and accuracy were determined by the analyses of duplicates and random insertion of standard samples according to the method of [10]. Both accuracy and precision were reasonable and satisfactory at the $95 \%$ confidence level.

\section{Data Analysis}

The results of the chemical analyses of the stream sediment samples for the following 29 elements were subjected to data analysis: $\mathrm{Ag}, \mathrm{As}, \mathrm{Au}, \mathrm{B}, \mathrm{Be}, \mathrm{Bi}, \mathrm{Co}, \mathrm{Cr}, \mathrm{Cu}$, 
$\mathrm{Ga}, \mathrm{Hg}, \mathrm{Hf}, \mathrm{La}, \mathrm{Mo}, \mathrm{Nb}, \mathrm{Ni}, \mathrm{Pb}, \mathrm{Pt}, \mathrm{Sb}, \mathrm{Sc}, \mathrm{Sr}, \mathrm{Ta}, \mathrm{Th}, \mathrm{Ti}$, $\mathrm{Tl}, \mathrm{U}, \mathrm{V}, \mathrm{W}$ and $\mathrm{Zn}$. Factor analysis was applied to 22 of the elements for which the Pearson correlation coefficients between pairs were also calculated, using the Statistical Package for Social Sciences (SPSS). The elements excluded from the analysis were $\mathrm{Hf}, \mathrm{Tl}, \mathrm{Be}, \mathrm{Ti}, \mathrm{Bi}$, Ta and Pt.

The total variance contained in each factor is re-expressed by the eigen value provided by the principal component solution as an initial set of uncorrelated linear transform of the original variables. The factor loadings, which can be considered as a combination between the elements, were computed after rotating the original principal component solution according to the Quartimax rotation method with Kaiser's normalization (Table 1). The element associations of a four-factor model and their eigen values in \% are presented in Table 2.

Figure 2 shows the sample sites superimposed on the geology of the study area. This is done for ease of interpretation and simplification. Factor score coefficients were tabulated and used to obtain cumulate factor scores. The correlation matrixes of factors are shown in Table 3. For this study, variables with loadings greater than 0.70 are considered significant groups of a particular factor.

Table 1. R-mode quartimax rotated factor matrix for 59 stream sediment samples (with 22 variables from the study area).

\begin{tabular}{|c|c|c|c|c|c|}
\hline Element 1 & Factor 1 & Factor 2 & Factor 3 & Factor 4 & Communality \\
\hline Mo & 0.442 & 0.253 & 0.576 & 0.147 & 0.613 \\
\hline $\mathbf{C u}$ & 0.717 & 0.420 & -0.002 & -0.007 & 0.696 \\
\hline $\mathbf{P b}$ & 0.795 & 0.247 & 0.344 & 0.006 & 0.816 \\
\hline $\mathbf{Z n}$ & 0.699 & 0.195 & 0.422 & 0.002 & 0.706 \\
\hline Ag & 0.853 & 0.078 & 0.307 & 0.004 & 0.829 \\
\hline $\mathbf{N i}$ & 0.882 & -0.073 & -0.371 & 0.122 & 0.935 \\
\hline Co & 0.881 & 0.081 & -0.265 & -0.007 & 0.853 \\
\hline As & 0.361 & 0.033 & -0.006 & 0.800 & 0.776 \\
\hline $\mathbf{U}$ & 0.396 & 0.786 & 0.298 & -0.006 & 0.868 \\
\hline Au & 0.357 & -0135 & 0.005 & 0.635 & 0.553 \\
\hline Th & 0.221 & 0.894 & -0.006 & -0.006 & 0.853 \\
\hline $\mathrm{Sr}$ & 0.802 & 0.174 & 0.357 & 0.001 & 0.801 \\
\hline $\mathbf{S b}$ & 0.140 & 0.421 & 0.176 & 0.415 & 0.401 \\
\hline $\mathbf{B i}$ & 0.816 & -0.137 & 0.244 & 0.117 & 0.757 \\
\hline $\mathbf{V}$ & 0.904 & 0.102 & -0.133 & 0.222 & 0.894 \\
\hline $\mathbf{L a}$ & 0.885 & 0.117 & -0.108 & -0.136 & 0.826 \\
\hline $\mathrm{Cr}$ & 0.703 & -0.164 & -0.374 & 0.406 & 0.826 \\
\hline Sc & 0.956 & -0.001 & -0.157 & 0.008 & 0.946 \\
\hline $\mathbf{H g}$ & 0.602 & -0.276 & 0.144 & -0.115 & 0.472 \\
\hline Ga & 0.945 & 0.006 & -0.009 & 0.007 & 0.912 \\
\hline Hf & 0.780 & -0.009 & -0.305 & 0.007 & 0.715 \\
\hline $\mathbf{N b}$ & 0.744 & -0.008 & 0.433 & -0.112 & 0.760 \\
\hline Eigen values & 11.321 & 2.169 & 1.753 & 1.563 & \\
\hline Proportion of total variance $\%$ & 51.461 & 9.858 & 7.969 & 7.105 & \\
\hline Cumulative (\%) & 51.461 & 61.319 & 69.288 & 76.392 & \\
\hline
\end{tabular}

Table 2. Shows the element associations of the four-factor model and the eigen value in (\%).

\begin{tabular}{ccc}
\hline Factors & Element association & Eigen values AS \% \\
\hline R-1 & Sc-Ga-V-La-Ni-Co-Ag-Bi-Sr-Pb-Hf-Nb-Cu-Cr & $51.46 \%$ \\
R-2 & Th-U & $9.86 \%$ \\
R-3 & Mo-Nb-Zn & $7.97 \%$ \\
R-4 & As-Au & $7.11 \%$ \\
\hline
\end{tabular}



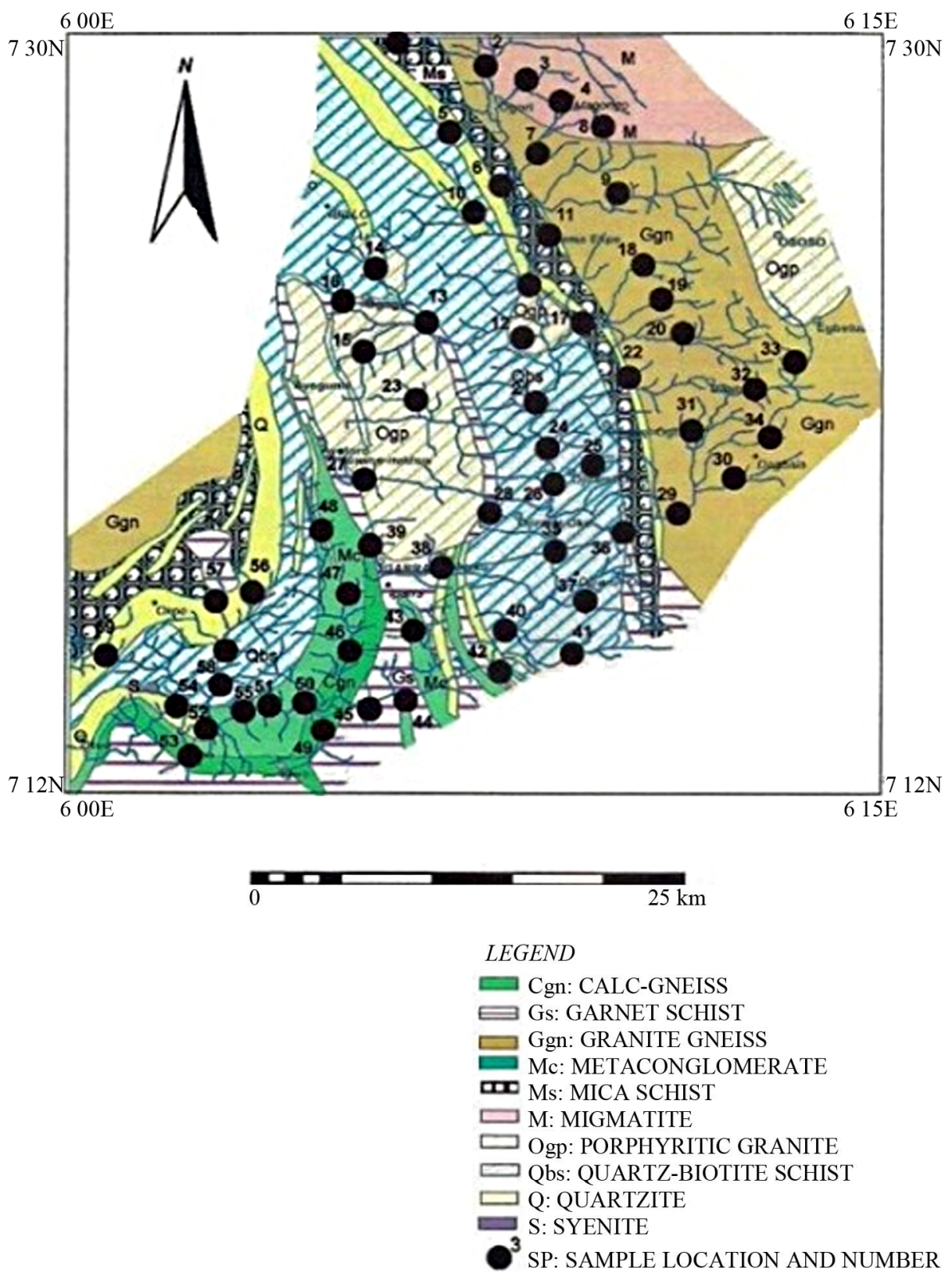

Figure 2. The geological map (modified after [11]) of the Onyami drainage system showing the sample locations.

\section{Results and Discussion}

The results of the factor analysis of fifty-nine stream sediment samples data set for the 22 elements, which constitute the variables in the analysis, are summarized using the Quartimax method. Table 2 shows factor loading, eigen values, variance cumulative $\%$ and the communality obtained from a four-factor model. The communality is an indication of the total variability of each element explained in a given factor model. The four-factor model explained $76.39 \%$ of the total variance.

The correlation matrix for the data obtained (Table 3) shows a wide variation in the correlation coefficient (r) between element pairs. For example, the $r$ values range from -0.01 between $\mathrm{Th}$ and $\mathrm{Au}$ to 0.94 between $\mathrm{Ga}$ and Sc. Fairly strong to very strong positive correlation occurs among Sc, Ga, V, Sr, Nb, La, Th, U and Hf, which is attributable to natural association of lithophile elements. Other elements which include $\mathrm{Ni}, \mathrm{Co}, \mathrm{Mo}, \mathrm{Cr}, \mathrm{Pb}$, $\mathrm{Cu}, \mathrm{Zn}, \mathrm{Ag}, \mathrm{As}, \mathrm{Sb}, \mathrm{Hg}, \mathrm{Bi}$ and $\mathrm{Co}$ indicate siderophile and chalcophile associations [12]. In the stream sediments, four factors with element associations were identified as the most meaningful solutions in terms of known geology, surficial environment and mineralization. The 


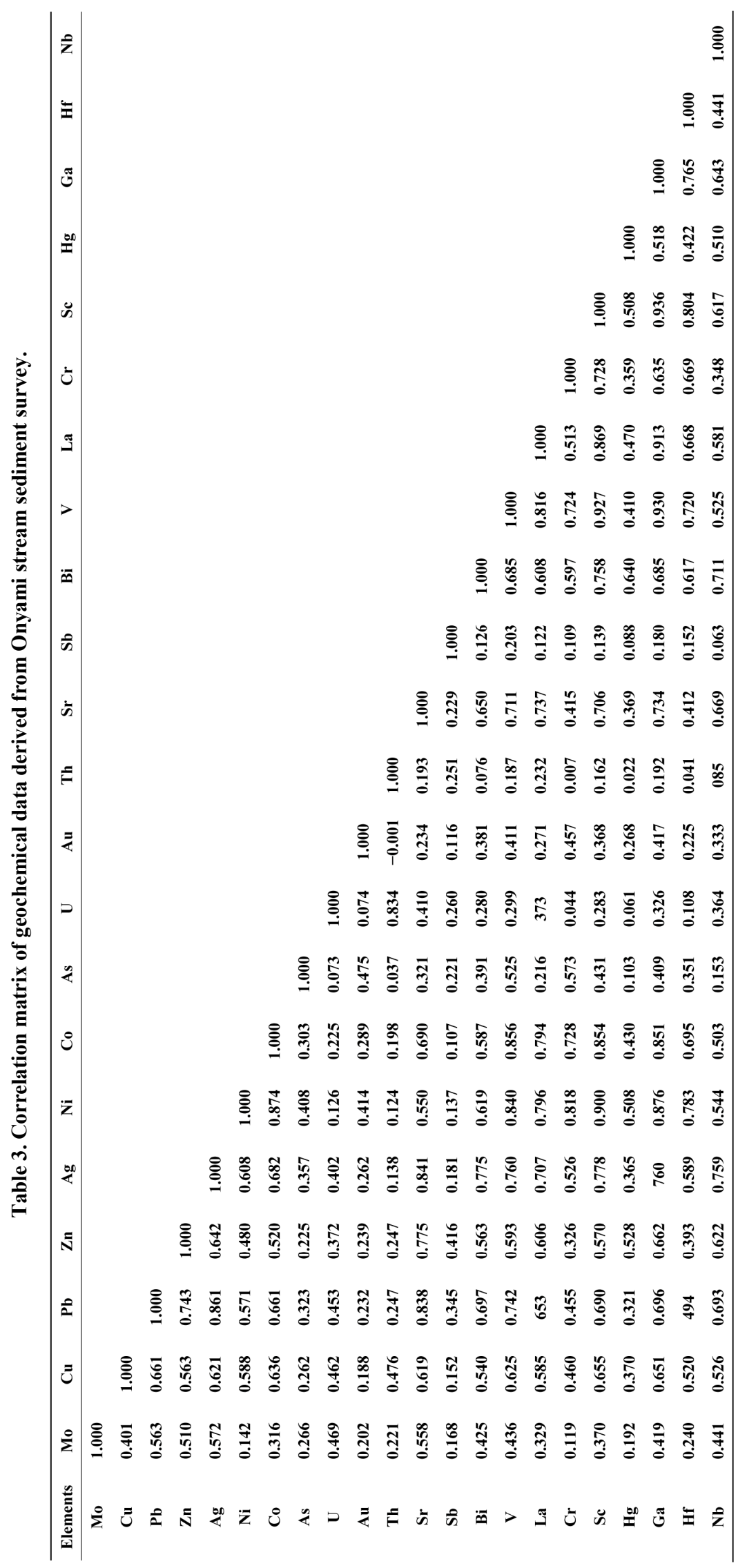


results of the four-factor model extracted from the logtransformed data are:

Factor 1: (Sc-Ga-V-La-Ni-Co-Ag-Bi-Sr-Pb-Hf-Nb-Cu$\mathrm{Cr})$. This is the most pronounced factor which accounts for $51.46 \%$ of the model variance and probably defines a combination of both mineralization and lithology. It is essentially a Sc factor. The Sc-Ga-V-La and Hf probably indicates a complex pegmatite lithology with veins and dykes being the source of the aforementioned trace elements. The association of Ag-Bi-Sr-Pb-Nb and $\mathrm{Cu}$ suggests the occurrence of probable sulphide mineralization. The very strong positive correlation of $\mathrm{V}, \mathrm{Sc}, \mathrm{Mo}, \mathrm{Ni}, \mathrm{Co}$ and $\mathrm{Cr}$ is probably indicative of the occurrence of mafic and ultramafic rocks within the study area.

Factor 2: (Th-U). This is the second factor and accounts for $9.86 \%$ of the model variance and seems to reflect the influence of the parent rock. The fairly strong correlation of $\mathrm{Th}, \mathrm{U}, \mathrm{Sb}$ and $\mathrm{Cu}$ suggest a granitic/pegmatitic lithology in the area.

Factor 3: (Mo-Nb-Zn). Factor 3 accounts for $7.97 \%$ of the variance of the four-factor model (Table 2). The fairly positive correlation between $\mathrm{Zn}$ and $\mathrm{Nb}$ suggests the presence and influence of a felsic lithology. Mo and $\mathrm{Zn}$ could also suggest the occurrence of sulphide mineralization probably associated with the felsic or granitic rock.

Factor 4: (As-Au). This factor accounts for $7.11 \%$ of the model variability and is considered a mineralization factor in view of the presence of As with $\mathrm{Au}$ in the factor. This association coupled with the fairly strong correlation among $\mathrm{Au}, \mathrm{As}$ and $\mathrm{Sb}$ strongly suggests the occurrence of Au mineralization in the study area. This is consistent with the reported occurrence and mining of gold in Dagbala area that falls within the study area [13].

\section{Conclusions}

Factor analysis is an aid to interpretation of reconnaissance stream sediment analytical data. The application of R-mode Quartimax rotated factor analysis accounted for a four-factor model in the stream sediments of Onyami drainage system.

The element associations identified in this study can be related either to underlying parent rocks (granitic suites with minor mafic rocks) and or mineralization. Minor sulphide mineralization of $\mathrm{Mo}, \mathrm{Cu}, \mathrm{Zn}, \mathrm{Pb}$, and $\mathrm{Ag}$ is likely to occur within the granitic rocks in the study area. Gold mineralization probably associated with complex sulphides is likely to occur in parts of the study area underlain by the metasediments (quartz-biotite schist, garnet schists, quartzites) and the granite gneisses $[3,4,14]$. The reported occurrence and mining of gold during the colonial era in Dagbala [13], which lies within the study area, lends credence to the inference of gold mineralization being present in the Onyami river catchment area.

\section{REFERENCES}

[1] R. Saager and A. J. Sinclair, "Factor Analysis of Stream Sediment Geochemical Data from the Mount Nansen Area, Yukon Territory, Canada," Mineralium Deposita, Vol. 9, No. 1, 1974, pp. 243-252.

[2] G. J. Woodsworth, "A Geochemical Drainage Survey and Its Implication for Metal Genesis, Central Coast Mountains, British Columbia," Economic Geology, Vol. 66, No. 8, 1971, pp. 1104-1120. doi:10.2113/gsecongeo.66.8.1104

[3] T. R. Ajayi, "Statistical Analysis of Stream Sediment Data from the Ife-Ilesa area of Southwestern Nigeria," Nigeria Journal of Mining and Geology, Vol. 15, No. 2, 1981, pp. 539-548.

[4] B. O. Bammeke, "Computer-aided Factor Analysis of Stream Sediment Geochemical Data from Igbo-Ora GreenstoneGranite Complex, Southwestern Nigeria," Nigeria Journal of Mining and Geology, Vol. 28, No. 1, 1992, pp. 113-117.

[5] A. A. Elueze, "Geological and Geochemical Studies in the Ilesha Schist Bels in Relation to Gold Mineralization,” M. Phil. Thesis, University of Ibadan, Ibadan, 1977.

[6] M. Woakes, M. A. Rahaman and A. C. Ajibade, "Some Metallogenic Features of the Nigerian Basement," Journal of African Earth Sciences, Vol. 6, No. 5, 1987, pp. 54-64.

[7] J. A. Adekoya, O. O. Kehinde-Phillips and A. M. Odukoya, "Geological Distribution of Mineral Resources in Southwestern Nigeria," In: A. A. Elueze, Ed., Prospects for Investment in Mineral Resources of Southwestern Nigeria, Nigerian Mining and Geosciences Society, Kaduna South, 2003, pp. 1-13.

[8] NGSA, "Geological Map of Nigeria," Nigerian Geological Survey Agency, 2006.

[9] I. B. Odeyemi, "Lithostratigraphy and Structural Relationships of the Upper Precambrian Metasediments in Igarra Area, Southwestern Nigeria," In: P. O. Oluyide, W. O. Mbonu, A. E. O. Ogezi, I. G. Egbuniwe, A. C. Ajibade and A. O. Umeji, Eds., Precambrian Geology of Nigeria, Geological Survey of Nigeria Publication, Kaduna South, 1988, pp. 111-125.

[10] M. Howarth and M. Thompson, "Duplicate Analysis in Geochemical Practice Part 1. Theoretical Approach and Estimation of Analytical Reproducibility," Analyst 101, 1978, pp. 690-698.

[11] I. B. Odeyemi, "On the Petrology of the Basement Rocks of Igarra, Former Bendel State of Nigeria," Ph.D. Thesis, University of Ibadan, Ibadan, 1977.

[12] A. W. Rose, H. E. Hawkes, and J. S. Webb, "Geochemistry in Mineral Exploration,” Academic Press, London, 1979.

[13] J. A. Adekoya, "Gold Deposits in Nigeria: A Summary of Available Information (Special Report)," Unpublished Geological Survey of Nigeria Report, Kaduna South, 1978.

[14] A. O. Oyinloye, "Analysis and Interpretation of Geochemical Data from Iperindo Lode Gold Deposit Using the Isochon Method," Global Journal of Pure and Applied Science, Vol. 6, No. 2, 2000, pp. 263-270. 